\section{Impact of Information and Communication Technology on Curbing Library Crimes in Academic Libraries in Nigeria}

\author{
Nonyelum P. Okpokwasili \\ Rivers State University, Nkpolu-Oroworukwo, \\ Port Harcourt, Nigeria
}

Information Impact: Journal of information and knowledge management

2018, Vol. 9 (4) Pg 130-141

ISSN: 2141 - 4297 (print)

ISSN: 2360 - 994X (e-version)

\begin{abstract}
The study adopted survey research design to investigate Impact of Information and Communication Technology on Curbing Library Crimes in Academic Libraries in Nigeria. The study covered state and federal higher institutions with academic libraries with a population of 542. A random sampling method was adopted with a sample size of 220 . The instrument used was a self-design with four point rating scale. 220 copies of questionnaire items were face-to-face administered to the respondents and successfully retrieved. From the findings of the study, it was concluded that there are high level of type of crimes committed in academic libraries and high level of curbing library crimes with ICT in academic libraries in Nigeria. Among other things, the study recommended that government and concerned authorities should adopt and make available information and communication technologies as means of curbing library crimes in academic libraries in Nigeria since the traditional methods seems not meeting the security expectations.
\end{abstract}

Keywords: Information and Communication Technology, Library Crimes, Delinquent users

\title{
Introduction
}

Libraries attached to polytechnics, colleges, universities, or other institutions of postsecondary education, are termed academic libraries and are aimed at meeting the information needs of students, faculty and staff. Academic libraries provide both print and electronic information materials for the use of the library users. Some of these library materials are to be read and kept back in the shelves but some are to be taken out of the library for use through lending (Okogwu, \& Nnam, 2013). The rate at which crimes are committed in the academic libraries and public and private properties stolen call for a total overhaul of the security system. Library crime, just like any other crimes, is of ancient origin. Theft or stealing of books, according to (Constantinou, 1995) can be traced as far back as 539 BC in Egypt when the Persian Conquerors removed rolls of Papyri from the library of Pharaoh Rameses II from circa 41BC. Ogunyade (2005) submits that library books were chain-locked to prevent theft.

Adewale and Oluwasanmi (2007) posit that book theft in academic libraries is a global problem pervasive in developing and developed countries. Library is an indispensable institution where valuable and relevant educational materials, both print and electronic, are stored for human consumption. Crime, on the other hand, is an act or omission to act which flouts the core values, rules and regulations guiding a particular establishment. By implication, library crime can be described as a process of using unauthorised method(s) to gain access to library materials, and this includes forging of Library Identification Particulars (LIP), mutilation, pilfering, theft or stealing, fraud, and the like. A lot of researchers deduced from the reports of these scholars that crime is widespread. Therefore, there is the need for 
Information and Communication Technologies installation such as burglar-proof, detection gadgets and other security precautionary measures in both public and private libraries in Nigeria to prevent and curb libraries crimes. According to Byrne and Marx (2011), technological innovation has been the driving force leading to reform of crime prevention, crime control and curbing strategies, both by individual citizens and concerned groups, and by formal police agencies (Reichert, 2001; Chan, 2001; Harris \& Lurigio, 2007). There are two general types of technological innovations that can be identified: information-based technologies (which will refer to here as soft technology) and material-based technologies (which will refer to here as hard technologies).

Both types of technological innovation have been linked to "dramatic changes in the organization of police" (Reichert, 2001), particularly at the turn of the last century, while similar linkages can be offered to more general crime prevention strategies employed by individuals, groups of residents and in the libraries. While the specific types of technologies acquired in this program varied from agency to agency, the most commonly acquired technologies were mobile data centers (MDCs) or laptops, followed by automated field reporting systems (AFRS), record management systems (RMS), personal computers, computer-Aided Dispatch (CAD) Systems, and Automated Fingerprint Identification Systems (AFIS). Of course, these technology expenditures only tell part of the technology implementation story. Recent review has documented the acquisition of a wide range of additional hard technology innovations during the last two decades, including new weapons, less-than-lethal force technologies, body armor, CCTV systems, gunshot location technology, and new patrol car technology which can also be applied in the academic libraries.

\section{Statement of the Problem}

The educational system in Nigeria is faced not only with the challenges of teaching and learning but also with insecurity in academic libraries. The traditional security system seems not to have been able to take care of the security needs of users, librarians and management. Therefore there is the need for adopting ICT in curbing library crimes in the academic libraries in Nigeria in order to conserve the scarce information resources. This prompted the researcher to come up with this present paper to support the existing body of literature on library crime.

\section{Purpose of the Study}

The purpose of this study is to find out the Impact of Information and Communication Technology in Curbing Library Crimes in Academic Libraries in Nigeria. The study specifically sought to:

1. Determine the level of types library crimes committed in academic libraries in Nigeria

2. Determine impact of Information and Communication Technology on curbing library crimes in academic libraries in Nigeria 


\section{Research Questions}

The under stated research questions were posed to guide this study

1. What is the level of types of library crimes committed in academic libraries in Nigeria?

2. What is the level of impact of Information and Communication Technologies on curbing library crimes in academic libraries in Nigeria?

\section{Hypotheses}

Two null hypotheses were formulated and tested at 0.05 level of significance

1. There is no level of types of library crimes committed in academic libraries in Nigeria

2. There is no level of impact of Information and Communication Technologies on curbing library crimes in academic libraries in Nigeria

\section{Literature Review}

\section{Library Crimes}

There exists legion of factors causing library crimes. These include economic, environmental, academic and social factors. (Akinfolarin,1992) detailed the cause of library crime in developed countries as follows: indigence of students, drastic reduction in book votes, poor security, belief that public property belongs to nobody in particular, selfishness on the part of some users, and absent-mindedness on the part of staff resulting in failure to properly check out books. The widespread poverty and high cost of living in Nigeria account for the various crimes in our academic libraries. No wonder Hogan-Bassey (2000) contended that most books in Nigeria are unaffordable by a majority of the students while the cost of living has gone up so high as to make living standard difficult for the low income group. Perhaps, against this background, Adewale and Oluwasanmi, (2007) argued that the problem of book theft in Nigeria is even more pronounced in these days of economic crunch when books are not only scarce but also their prices are exorbitant.

Lending credence to the above assertion, Ogunyade (2005) reveals that library crime is caused by many factors, which include inadequate volume of books, poverty on the part of students, short period of loaning by the library, and selfishness on the part of the students to hide library books illegally. Arguing from the same direction, Bello,( 2001) suggested that the major causes of library crime in Nigerian University Libraries are the inability of these Libraries to adequately cope with the increase in student's population, introduction of new courses and expansion of existing ones. This is exacerbated by insufficient funding from Federal and State Governments (Adewale \& Oluwasanmi, 2007). Another factor that increases the incidence of crime and wrong doing in a University or College Library is the unusually large number of students in a class (Hogan-Bassey, 2000). A lot of studies have linked crime and deviance to social, economy, environmental and library factors, (Ishaya, 1995, Ogunyade, 2005). Social environment as a determinant of crime is certainly not a recent development in crime. The environmental nature of libraries in the manner of social organisation and social conditions like overcrowding with its concomitant induce crime in all its ramifications. 
Adewuyi and Adekanye (2011) listed the following methods adopted in stealing information resources:

I. Hiding libraries items in their clothes

II. Throwing stolen item(s) through the window and door when people are not observing

III. Putting library item(s) in handbag or briefcase

IV. Collaborating with library staff to steal library collection

V. Selling of library books by library staff to supplement poor monthly salary and making friends with porters before carrying out their illegitimate plans.

VI. Others are, Book theft, Book mutilation, Non-return borrowed books, using fake Identity cards to borrow books, mis-shelving of books, noise making in library, eating in the library and engaging in illicit discussions.

\section{Impact ICT on Curbing Libraries Crimes in Nigeria}

Computerized Charging System: Libraries adopt various types of charging system, such as Browne Charging System, etc. Some libraries have computerised their charging system to make their operations faster. Whichever system a library adopts, it is one of the means of detecting stolen books since due dates are always on the date due slip of each book borrowed. Use of Electronic Exit Control: In order to minimise the occurrence of crimes in the library, exit controls are necessary. Some libraries use turnstiles and guards to slow down movements of users and check patrons going out at the exit. Libraries in developed countries mostly use electric security system at their exits. Adopting electronic exit control system will assist a lot in curbing library crimes.

Installation of Close Circuit Television (CCTV): Electronic security system like Close Circuit Television (CCTV) should be installed in academic libraries. CCTV is a specially designed crime detection gadget that monitors the activities and movements of people within its scope. This will enable easy prediction, prevention, control and library crimes curbing. It will lead to the academic library crimes to be nibbed on the board (Okogwu \& Nnam, 2013).

Use of MDC, ARFS, RMS, CADS and AFIS: While specific types of technologies acquired in this program varied from agency to agency, the most commonly acquired technologies were mobile data centers (MDCs) or laptops, followed by automated field reporting systems (AFRS), record management systems (RMS), personal computers, computer-Aided Dispatch (CAD) Systems, and Automated Fingerprint Identification Systems (AFIS). These technologies can assist seriously in curbing academic libraries crimes in Nigeria.

Introduction of Soft Technologies: Soft technologies involve strategic use of information to prevent crime (e.g. the development of risk assessment, and threat assessment instruments) and to improve the performance of the policing an area like predictive policing technology, and recording/video streaming capabilities in police vehicles that could be installed in the libraries. Soft technology innovations include new software programs, classification systems, crime analysis techniques, and data sharing/ system integration techniques to record, store analyse as well as curb crimes. Some of the soft and hard technologies on the table can be used to curb crimes in libraries in Nigeria. See figure 1 below: 
Figure1: The Application of Hard and Soft Technology to Crime Prevention and Police

\begin{tabular}{|c|c|c|}
\hline & HARD Technology & SOFT Technology \\
\hline $\begin{array}{l}\text { Crime } \\
\text { Prevention/ } \\
\text { Curbing }\end{array}$ & $\begin{array}{l}\text { CCTV } \\
\text { Street/ library lighting } \\
\text { - citizen protection } \\
\text { devices(e.g. mace, } \\
\text { tasers) } \\
\text { metal detectors, } \\
\text { ignition interlock } \\
\text { systems(drunk drivers) }\end{array}$ & $\begin{array}{l}\text { Threat assessment instruments } \\
\text { risk assessment instruments } \\
\text { Bullying ID protocol } \\
\text { - sex offender registration } \\
\text { - risk assessment prior to involuntary civil } \\
\text { Commitment } \\
\text { - profiling potential offenders } \\
\text { - facial recognition software used in } \\
\text { conjunction with CCTV }\end{array}$ \\
\hline Police/Security & $\begin{array}{l}\text { Improved police/security } \\
\text { protection } \\
\text { devices(helmets, vests, cars, } \\
\text { buildings) } \\
\text { Improved/new weapons } \\
\text { - less than lethal force } \\
\text { (mobile/ riot } \\
\text { control) } \\
\text { - computers in squad cars } \\
\text { - offender and citizen ID's } \\
\text { via biometrics/ Fingerprints } \\
\text { mobile data center around } \\
\text { video tapes in the library }\end{array}$ & $\begin{array}{l}\text { - Crime mapping (hot spots) } \\
\text { - Crime analysis (e.g. COMPSTAT) } \\
\text { - Criminal history data systems enhance- } \\
\text { Ment } \\
\text { - Info sharing w/in CJS and private sector } \\
\text { - New technologies to monitor communi- } \\
\text { cations( phone, mail, internet) to/from } \\
\text { targeted individuals } \\
\text { - Amber alerts } \\
\text { - Creation of watch lists of potential violent } \\
\text { Offenders } \\
\text { - gunshot location devices }\end{array}$ \\
\hline
\end{tabular}

Source: Byrne and Marx (2011)

Installation of Surveillance Tapes and Chips in libraries Books: Things like video tapes if installed in the libraries can assist in curbing crimes. ICT has introduced a lot of things which prevent people from committing crime. CCTV camera, GPRS system, using database for finding criminals' information are some unique things which cannot be possible without ICT. Today world class police use GPRS to track someone's car, mobile phone if it has been stolen. Police use CCTV camera to detect criminals' face. Fingerprint is another special method with which the police can identify thieves. This is making our life safer and very easy in many ways. For example, in big super markets like ASDA, SPAR or Tesco, they do not need to think too much if someone tries to still their products, because some products have got chips which can be detected if that product is not swiped over the bar code reader. The same can be done to library books and materials, (Ukata, 2018) 
Generally, alarm security system consists of 5 parts. These are:

i. Security sensor or detectors

ii. Gate entering alarm

iii. Perimeter protection defence

iv. Video record linkage and CCTV camera

v. Network alarm report or sending.

These five (5) parts can be applied independently or integrated according to actual requirement. These principles say, the alarm security system should be assured of safety and reliability in it application. A computer security (or cyber security or IT security) is applied to computer and computer networks. This field covers all processes and mechanisms by which computer-based equipment, information and services are protected from unauthorized access and destruction. The libraries in Nigeria can adopt this independently or integrated in crimes prevention and curbing (Ukata, 2018)

\section{Methodology}

The study adopted a survey research design to determine Impact of Information and Communication Technology on Curbing Library Crimes in Academic Libraries in Nigeria. The study covered Rivers State University (RSU), Ignatius Ajuru University of Education (IAUE), University of Port Harcourt (UNIPORT) and Captain Elechi Amadi Polytechnic (CEAPOLY) and Ken Sarowiwa Polytechnic (KENPOLY), Bori. Students from above stated higher institutions constituted the population of the study. Students from Department of Office and Technology Management at CEAPOLY and KENPOLY, Department of Office and Information Management at RSU, Department of Secretarial Studies at IAUE and Department of Business Education at UNIPORT were carefully selected to form a population of 542 ranging from National Diploma II, Higher National Diploma II, Year 2, Year 3 and Year 4. National Diploma I and Year 1 students were not included in the study because they may not be able to give a fair assessment on the use of library due to their newness in the higher institutions. A random sampling technique was adopted. Krejcie and Morgan (1970) method was used to determine the sample size of 220. The instrument used was tagged: "Impact of Information and Communication Technology in Curbing Library Crimes in Academic Libraries (IICTCLCAL)", with a four point scale of Very High Level Impact on Curbing Library Crimes (4 points), High Level of Impact (3 points), Low Level of Impact (2 points) and Very Low Level of Impact (1 point). The instrument was validated by three experts and a field trial of test retest was done to know the internal consistency which yielded 0.89 co-efficient. 220 copies of questionnaire items were face-to-face administered to the respondents and all successfully retrieved. Arithmetic mean was used to analyse the research questions, and Standard Deviation used to find out the extent in which scores in the distribution clustered around the means. T-test was adopted to test the two hypotheses. The decision point was that any calculated grand mean from 2.5 and above was accepted and any ground mean below 2.5 was rejected. Also, any calculated value of T-test that is greater than $>$ the critical table value of 1.96 at 0.05 significant levels such null hypothesis $\left(\mathrm{H}_{\mathrm{O}}\right)$ will be rejected, but if the critical table value is greater than $>$ the computed value such null hypothesis will be accepted. 


\section{Findings and discussion}

Research Question 1: What is the level of types of library crimes committed in academic libraries in Nigeria?

Table 1: Computation of Mean and Standard Deviation of the Level of Types of Library Crimes Committed in Academic Libraries in Nigeria

\begin{tabular}{|c|c|c|c|c|c|c|c|c|c|}
\hline \multicolumn{10}{|c|}{ N = 220, TNR = Total Number of Response } \\
\hline $\mathrm{SN}$ & Item statement & $\begin{array}{l}\text { VHLT } \\
\text { C } 4\end{array}$ & $\begin{array}{l}\text { HLTC } \\
3\end{array}$ & $\begin{array}{l}\text { LLTC } \\
2\end{array}$ & $\begin{array}{l}\text { VLL } \\
\text { TC } \\
1\end{array}$ & $\begin{array}{l}\text { TR } \\
\mathbf{N}\end{array}$ & $\mathbf{X}$ & SD & $\begin{array}{l}\text { Rema } \\
\text { rk }\end{array}$ \\
\hline 1 & $\begin{array}{l}\text { Non-return borrowed } \\
\text { books }\end{array}$ & $\begin{array}{l}\text { 120(48 } \\
0)\end{array}$ & $\begin{array}{l}100(30 \\
0)\end{array}$ & $0(0)$ & $0(0)$ & $\begin{array}{l}78 \\
0\end{array}$ & 3.5 & 0.8 & $\begin{array}{l}\text { HLT } \\
\text { C }\end{array}$ \\
\hline 2 & Book theft, & $\begin{array}{l}\text { 110(44 } \\
0)\end{array}$ & $70(210)$ & $40(80)$ & $0(0)$ & $\begin{array}{l}73 \\
0\end{array}$ & 3.3 & 0.8 & $\begin{array}{l}\text { HLT } \\
\text { C }\end{array}$ \\
\hline 3 & Book mutilation & $\begin{array}{l}\text { 120(48 } \\
0)\end{array}$ & $\begin{array}{l}\text { 100(30 } \\
0)\end{array}$ & $0(0)$ & $0(0)$ & $\begin{array}{l}78 \\
0\end{array}$ & 3.5 & 0.8 & $\begin{array}{l}\text { HLT } \\
\text { C }\end{array}$ \\
\hline 4 & $\begin{array}{l}\text { Putting library item(s) } \\
\text { in handbag or briefcase }\end{array}$ & $\begin{array}{l}100(40 \\
0)\end{array}$ & $\begin{array}{l}100(30 \\
0)\end{array}$ & $20(40)$ & $0(0)$ & $\begin{array}{l}74 \\
0\end{array}$ & 3.4 & 0.8 & $\begin{array}{l}\text { HLT } \\
\text { C }\end{array}$ \\
\hline 5 & $\begin{array}{l}\text { Hiding libraries items } \\
\text { in their clothes }\end{array}$ & $\begin{array}{l}110(44 \\
0)\end{array}$ & $\begin{array}{l}\text { 100(30 } \\
0)\end{array}$ & $10(20)$ & $0(0)$ & $\begin{array}{l}76 \\
0\end{array}$ & 3.5 & 0.8 & $\begin{array}{l}\text { HLT } \\
\text { C }\end{array}$ \\
\hline 6 & $\begin{array}{l}\text { Throwing stolen item(s) } \\
\text { through the window } \\
\text { and door }\end{array}$ & $\begin{array}{l}100(40 \\
0)\end{array}$ & $\begin{array}{l}\text { 100(30 } \\
0)\end{array}$ & $20(40)$ & $0(0)$ & $\begin{array}{l}74 \\
0\end{array}$ & 3.4 & 0.8 & $\begin{array}{l}\text { HLT } \\
\text { C }\end{array}$ \\
\hline 7 & $\begin{array}{lll}\text { Collaborating with } \\
\text { library staff to steal } \\
\text { library collection }\end{array}$ & $\begin{array}{l}130(52 \\
0)\end{array}$ & $90(270)$ & $0(0)$ & $0(0)$ & $\begin{array}{l}79 \\
0\end{array}$ & 3.6 & 0.9 & $\begin{array}{l}\text { HLT } \\
\text { C }\end{array}$ \\
\hline 8 & $\begin{array}{l}\text { Selling of library books } \\
\text { by library staff }\end{array}$ & $\begin{array}{l}100(40 \\
0)\end{array}$ & $\begin{array}{l}100(30 \\
0)\end{array}$ & $20(40)$ & $0(0)$ & $\begin{array}{l}74 \\
0\end{array}$ & 3.4 & 0.8 & $\begin{array}{l}\text { HLT } \\
\text { C }\end{array}$ \\
\hline 9 & $\begin{array}{l}\text { Using fake ID cards to } \\
\text { borrow books, }\end{array}$ & $\begin{array}{l}150(60 \\
0)\end{array}$ & $70(210)$ & $0(0)$ & $0(0)$ & $\begin{array}{l}81 \\
0\end{array}$ & 3.7 & 0.9 & $\begin{array}{l}\text { HLT } \\
\text { C }\end{array}$ \\
\hline 10 & $\begin{array}{l}\text { Eating and engaging in } \\
\text { illicit discussions. }\end{array}$ & $\begin{array}{l}140(56 \\
0)\end{array}$ & $80(240)$ & $0(0)$ & $0(0)$ & $\begin{array}{l}80 \\
0\end{array}$ & 3.6 & 0.9 & $\begin{array}{l}\text { HLT } \\
\text { C }\end{array}$ \\
\hline & Grand mean & & & & & & 3.5 & & $\begin{array}{l}\text { HLT } \\
\text { C }\end{array}$ \\
\hline
\end{tabular}

\section{Researcher's Field Survey, 2018}

The grand mean of table 1 showed 3.5, representing high level of type of crimes committed in academic libraries in Nigeria. The least standard deviation was 0.8 , while the highest in the table was 0.9 , representing closeness in the views of the respondents. 
Research Question 2: What is the level of impact of Information and Communication Technologies on curbing library crimes in academic libraries in Nigeria?

Table 2: Computation of Mean and Standard Deviation of the Level of Impact of ICT on Curbing Library Crimes in Academic Library in Nigeria

\begin{tabular}{|c|c|c|c|c|c|c|c|c|c|}
\hline \multicolumn{10}{|c|}{ N = 220, TNR = Total Number of Response } \\
\hline $\mathrm{SN}$ & Item statement & $\begin{array}{l}\text { VHLI } \\
\text { CC } 4\end{array}$ & $\begin{array}{l}\text { HLIC } \\
\text { C } 3\end{array}$ & $\begin{array}{l}\text { LLIC } \\
\text { C } 2\end{array}$ & $\begin{array}{l}\text { VLLIC } \\
\text { C } 1\end{array}$ & $\begin{array}{l}\text { TR } \\
\mathbf{N}\end{array}$ & $\mathbf{X}$ & $\begin{array}{l}\text { S } \\
\text { D }\end{array}$ & $\begin{array}{l}\text { Rema } \\
\text { rk }\end{array}$ \\
\hline 1 & Computerized Charging System & $\begin{array}{l}\text { 150(60 } \\
0)\end{array}$ & $\begin{array}{l}70(21 \\
0)\end{array}$ & $0(0)$ & $0(0)$ & $\begin{array}{l}81 \\
0\end{array}$ & $\begin{array}{l}3 . \\
7\end{array}$ & $\begin{array}{l}0 . \\
9\end{array}$ & $\begin{array}{l}\text { HLIC } \\
\text { C }\end{array}$ \\
\hline 2 & Use of Electronic Exit Control & $\begin{array}{l}140(56 \\
0)\end{array}$ & $\begin{array}{l}80(24 \\
0)\end{array}$ & $0(0)$ & $0(0)$ & $\begin{array}{l}80 \\
0\end{array}$ & $\begin{array}{l}3 . \\
6\end{array}$ & $\begin{array}{l}0 . \\
9\end{array}$ & $\begin{array}{l}\text { HLIC } \\
\text { C }\end{array}$ \\
\hline 3 & $\begin{array}{l}\text { Installation of Close Circuit } \\
\text { Television (CCTV) }\end{array}$ & $\begin{array}{l}\text { 200(80 } \\
0)\end{array}$ & $\begin{array}{l}20(60 \\
)\end{array}$ & $0(0)$ & $0(0)$ & $\begin{array}{l}86 \\
0\end{array}$ & $\begin{array}{l}3 . \\
9\end{array}$ & $\begin{array}{l}0 . \\
9\end{array}$ & $\begin{array}{l}\text { HLIC } \\
\text { C }\end{array}$ \\
\hline 4 & $\begin{array}{l}\text { Use of MDC, ARFS, RMS, } \\
\text { CADS \& AFIS }\end{array}$ & $\begin{array}{l}\text { 190(76 } \\
0)\end{array}$ & $\begin{array}{l}30(90 \\
)\end{array}$ & $0(0)$ & $0(0)$ & $\begin{array}{l}85 \\
0\end{array}$ & $\begin{array}{l}3 . \\
9\end{array}$ & $\begin{array}{l}0 . \\
9\end{array}$ & $\begin{array}{l}\text { HLIC } \\
\text { C }\end{array}$ \\
\hline 5 & $\begin{array}{l}\text { Introduction } \quad \text { of } \quad \text { Soft } \\
\text { Technologies }\end{array}$ & $\begin{array}{l}\text { 195(78 } \\
0)\end{array}$ & $\begin{array}{l}25(75 \\
)\end{array}$ & $0(0)$ & $0(0)$ & $\begin{array}{l}85 \\
5\end{array}$ & $\begin{array}{l}3 . \\
9\end{array}$ & $\begin{array}{l}0 . \\
9\end{array}$ & $\begin{array}{l}\text { HLIC } \\
\text { C }\end{array}$ \\
\hline 6 & Threat assessment instruments & $\begin{array}{l}\text { 185(74 } \\
0)\end{array}$ & $\begin{array}{l}35(10 \\
5)\end{array}$ & $0(0)$ & $0(0)$ & $\begin{array}{l}84 \\
5\end{array}$ & $\begin{array}{l}3 . \\
8\end{array}$ & $\begin{array}{l}0 . \\
9\end{array}$ & $\begin{array}{l}\text { HLIC } \\
\text { C }\end{array}$ \\
\hline 7 & Risk assessment instruments & $\begin{array}{l}\text { 190(76 } \\
0)\end{array}$ & $\begin{array}{l}30(90 \\
)\end{array}$ & $0(0)$ & $0(0)$ & $\begin{array}{l}85 \\
0\end{array}$ & $\begin{array}{l}3 . \\
9\end{array}$ & $\begin{array}{l}0 . \\
9\end{array}$ & $\begin{array}{l}\text { HLIC } \\
\text { C }\end{array}$ \\
\hline 8 & $\begin{array}{l}\text { Use of surveillance tapes and } \\
\text { chips }\end{array}$ & $\begin{array}{l}\text { 210(84 } \\
0)\end{array}$ & $10(30$ & $0(0)$ & $0(0)$ & $\begin{array}{l}87 \\
0\end{array}$ & $\begin{array}{l}4 . \\
0\end{array}$ & $\begin{array}{l}0 . \\
9\end{array}$ & $\begin{array}{l}\text { HLIC } \\
\text { C }\end{array}$ \\
\hline & Grand mean & & & & & & $\begin{array}{l}3 . \\
8\end{array}$ & & $\begin{array}{l}\text { HLIC } \\
\text { C }\end{array}$ \\
\hline
\end{tabular}

\section{Researcher's Field Survey, 2018}

The grand mean of table 1 showed 3.8, representing high level of impact of curbing crimes with ICT in academic libraries in Nigeria. The least standard deviation and highest on the table was 0.9 ; signifying closeness in the views of the respondents.

\section{Hypotheses}

Hypothesis1: There is no level of types of library crimes committed in academic libraries in Nigeria 
Table 3: Summary Table of Calculated T-test of the Level of Types of Library Crimes Committed in Academic Libraries in Nigeria

\begin{tabular}{|c|c|c|c|c|c|c|c|c|c|}
\hline SN & Variables & $\begin{array}{l}\text { Mea } \\
\text { n }\end{array}$ & SD & $\mathbf{N}$ & DF & SE & $\begin{array}{l}\text { T- } \\
\text { CAL. }\end{array}$ & $\begin{array}{l}\text { T- } \\
\text { TAB }\end{array}$ & DECISION \\
\hline \multirow[t]{2}{*}{1} & $\begin{array}{l}\text { Level Types of } \\
\text { Crimes }\end{array}$ & 3.5 & 0.9 & 220 & & $\begin{array}{l}0.0 \\
7\end{array}$ & & & \\
\hline & & & & & $\begin{array}{l}21 \\
8\end{array}$ & & 2.97 & 1.96 & Rejected \\
\hline 2 & $\begin{array}{l}\text { Academic Library } \\
\text { in Nigeria }\end{array}$ & 3.5 & 0.8 & 220 & & $\begin{array}{l}0.0 \\
6\end{array}$ & & & \\
\hline
\end{tabular}

\section{Researcher's Field Survey, 2018}

The calculated t-test 2.97 is greater than (>) the critical table value of 1.96 at 0.05 significant levels. Since the calculated value of t-test 2.97 is greater than $(>)$ the critical table value of 1.96, the null hypothesis which stated that there is no level of types of library crimes committed in academic libraries in Nigeria is rejected. This means that there is level of types of library crimes committed in academic libraries in Nigeria

Hypothesis 2: There is no level of impact of Information and Communication Technologies on curbing Library crimes in academic libraries in Nigeria

Table 4: Summary Table of Calculated T-test of the Level of Impact of ICT on Curbing Library Crimes in Academic Libraries in Nigeria

\begin{tabular}{llllllllll}
\hline SN & Variables & Mean & SD & N & DF & SE & $\begin{array}{l}\text { T- } \\
\text { CAL. }\end{array}$ & $\begin{array}{l}\text { T- } \\
\text { TAB }\end{array}$ & DECISION \\
\hline 1 & $\begin{array}{l}\text { The Level of } \\
\begin{array}{l}\text { Impact of ICT } \\
\text { 3.8 }\end{array}\end{array}$ & $\mathbf{0 . 9}$ & $\mathbf{2 2 0}$ & & $\mathbf{0 . 0 8}$ & & & \\
2 & $\begin{array}{l}\text { Curbing } \\
\text { Academic } \\
\text { Libraries Crimes } \\
\text { in Nigeria }\end{array}$ & 3.3 & $\mathbf{0 . 9}$ & $\mathbf{2 2 0}$ & & $\mathbf{0 . 0 7}$ & & & \\
\hline
\end{tabular}

Researcher's Field Survey, 2018

The calculated t-test 2.99 is greater than (>) the critical table value of 1.96 at 0.05 significant levels. Since the calculated value of t-test 2.99 is greater than $(>)$ the critical table value of 1.96, the null hypothesis which stated that there is no level of impact of Information and Communication Technologies on curbing library crimes in academic libraries in Nigeria is rejected. This means that there is high level of impact of Information and Communication Technologies on curbing library crimes in academic libraries in Nigeria. 


\section{Discussion of Findings}

From the analysis of research question one and table one, the grand mean showed 3.5, representing high level of type of library crimes committed in academic libraries in Nigeria. The views of the respondents is in agreement with the opinions of Adewuyi and Adekanye (2011) who listed Book theft, Book mutilation, Non-return borrowed books, Using fake ID cards to borrow books, Mis-shelving of books, Noise making in library, Eating in the library and engaging in illicit discussions as some of the crimes committed in academic libraries in Nigeria. Also from the analysis of research question two and table two, the grand mean showed 3.8, representing high level of impact of ICT on curbing library crimes in academic libraries in Nigeria. The views of the respondents is in agreement with Olanlokun \& Salisu (1985), Okogwu \& Nnam (2013), Byrne \& Marx (2011) and Ukata (2018) who saw Computerized Charging System, Use of Electronic Exit Control, Installation of Close Circuit Television (CCTV), Use of MDC, ARFS, RMS, CADS \& AFIS, Introduction of Soft Technologies, Threat assessment instruments, Risk assessment instruments and Use of surveillance tapes and chips as ways of using information and communication technologies to limit library crimes in academic libraries in Nigeria.

\section{Conclusion and Recommendations}

From the findings of the study it is concluded that there are high level of library crimes committed in academic libraries in Nigeria and also high level of impact of Information and Communication Technologies intervention in curbing same in academic libraries in Nigeria

1. Government and concerned authorities should adopt and make available information and communication technologies as mean of curbing library crimes in academic libraries in Nigeria since the traditional methods seem not to be meeting the security expectations.

2. There should be adequate funding from government and other concerned agencies for regular training and retraining of Librarians to meet the current trend of libraries security management.

3. There should be regular and adequate orientations, including advertisement for students and the public on the need on joining hands to protect academic libraries' information resources instead of stealing and destroying them

\section{References}

Adewuyi, O.W. \& Adekanye, E.A. (2011). Strategy for prevention of crime in Nigerian university libraries: The experience of the University of Lagos. Library and Archival Security 24 (1): 127-140. http://www.tandf.co.uk/journals/tiokoye.htmtles/01960075.asp

Adewale, T.O. and Oluwasanmi, H. (2007). Book theft and its prevention in Nigerian academic libraries. Gateway Library Journal, 10 (1): 73-84. 
Akinfolarin, W.A. (1992). Towards improved security measures in Nigerian university libraries. African Journal of Library, Archives and Information Science, 2 (1): 51-56

Bello, A.S. (2001). Library use malpractices: A case study of the Ibadan Polytechnic Library. Nigerian Libraries, 35 (1): 23-32.

Byrne, J. M. \& Marx, G. T. (2011). Technological innovations in crime prevention and policing: A review of the research on implementation and impact. Journal of Police Studies, 20 (3): 17-40

Constantinou, C. (1995). Destruction of knowledge: A study of journal mutilation at a large University Library. College and Research Libraries, 56(2): 497-507.

Chan, J. (2001). The technology game: How information technology is transforming police practice. Journal of Criminal Justice, 1(1), 139-159.

Harris, A. \& Lurigio, A. (2007). Crime prevention and soft technology: Risk assessment, threat assessment, and the prevention of violence. The New Technology of Crime, Law and Social Control, 1(2): 103-132

Hogan-Bassey, 1 (2000). Library crimes and technology. Nigerian Libraries, 34 (2): $29-40$.

Ishaya, J. L. (1995). Reason behind theft and mutilation of library materials in Polytechnics. In E. A. Oladere and G. Oladipo (Eds.), Effective management of Polytechnic Libraries: Library security. Proceedings of the NBTE Workshop held in Kaduna, 3-31 May, 1995.

Krejcie, R. V. \& Morgan, D. W. (1970). Determining sample size for research activities. Educational and Psychological Measurement, 30: 607-610

Ogunyade, T.O. (2005). Theft and mutilation in an academic library: College of Medicine, University of Lagos Experience. Nigeria Quarterly Journal Hospital Medical, 15 (2): 1-10. http://www.unilag.edu.ng/opendoc.phpsno=14918\&doctype $=$ do

Okogwu, F. I. \& Nnam, U. M. (2013). The sociology of library crime in Nigerian academic libraries. Library Philosophy and Practice (e-journal), 94. http://digitalcommons.unl.edu/libphilprac/949

Olanlokun, S.O. \& Salisu, T.M. (1985). Understanding the library: A handbook on library Use. Kano: Concept Publication Ltd. 
Reichert, K. (2001). Use of information technology by Law Enforcement: Promising approaches to addressing crime series. University of Pennsylvania: Jerry Lee Center of Criminology, Forum on Crime and Justice.

Ukata, P. F. (2018). Foundation of ICT theory and practical steps for students and office workers. Port Harcourt: Agipea Global Service. 